\title{
PENGARUH LATIHAN FOREHAND KE DINDING TERHADAP HASIL FOREHAND DRIVE TENIS MEJA SISWA SMP NEGERI 1 TANJUNG BATU
}

\author{
Oleh: Novri Asri, M. Pd. \\ (Universitas Islam Kalimantan Muhammad Arsyad Al Banjari Banjarmasin) \\ Novriasri.na@gmail.com
}

\begin{abstract}
Abstrak
Penelitian ini bertujuan untuk mengetahui apakah ada pengaruh latihan forehand ke dinding terhadap hasil forehand drive tenis meja pada siswa putra Sekolah Menengah Pertama Negeri 1 Tanjung Batu. Untuk mengetahui apakah latihan forehand ke dinding memberikan pengaruh terhadap hasil forehand drive tenis meja, peneliti melakukan pretest dan posttest dengan menggunakan metode backboard, hasil dari pretest dan posttest dianalisis dengan menggunakan "uji t". Berdasarkan hasil uji t ini diperoleh perbedaan dari hasil pretest dan posttest. Hal ini terlihat dari peningkatan rata-rata pretest dan posttest dari 9,45 ke 11,3 atau naik sebesar 1,85. Selain itu dilihat dari hasil uji t menunjukkan hasil t hitung yang didapat adalah 18, sedangkan t tabel adalah 1,70 diperoleh dari tabel distribusi $t$ dengan dk (40) maka 40-1=39 dan taraf kepercayaan 95\% $(\alpha=0,05)$, dengan demikian maka hipotesis $H_{0}$ ditolak dan hipotesis $H_{1}$ diterima. Berdasarkan hasil tersebut dapat disimpulkan bahwa ada pengaruh latihan forehand ke dinding terhadap hasil forehand drive tenis meja pada siswa putra Sekolah Menengah Pertama Negeri 1 Tanjung Batu.
\end{abstract}

Kata Kunci: Forehand ke Dinding, Forehand Drive, Tenis Meja.

\section{EFFECT OF FOREHAND TRAINING TO THE WALL AGAINST THE RESULT FOREHAND DRIVE TABLE TENNIS ON STUDENTS JUNIOR HIGH SCHOOL NUMBER 1 TANJUNG BATU}

\begin{abstract}
The study aims to find out if there is any influence of effect of forehand training to the wall against the result forehand drive table tennis on students Junior High School Number 1 Tanjung Batu. To find out if the forehand exercise to the wall affects the results of table tennis forehand, researchers do Pretest and posttest using the backboard method, the results of Pretest and posttest are analyzed using the " $\mathrm{T}$ "Test. Based on the results of these $\mathrm{T}$ tests obtained differences from the results of pretests and posttest. It is
\end{abstract}


seen from the average increase of pretests and posttest from 9.45 to 11.3 or up to 1.85 . Besides judging from the results of the test $\mathrm{T}$, $\mathrm{T}$ Count obtained is 18 , whereas $\mathrm{T}$ table is 1, 70 obtained from distribution table $\mathrm{T}$ with DK (40) then $40-1=39$ and Confidence level 95\% $(\alpha=0.05)$, Thus the H0 hypothesis was rejected and the H1 hypothesis was received. Based on the results it can be concluded that there is an effect of forehand training to the wall against the result forehand drive table tennis on students Junior High School Number 1 Tanjung Batu.

\section{Keywords: Forehand to Wall, Forehand Drive, Table Tennis.}

Correspondence author: Novri Asri, Universitas Islam Kalimantan Muhammad Arsyad Al Banjari, Indonesia. Novriasri.na@gmail.com

\section{(c) (i) (2)}

Jurnal Halaman Olahraga Nusantara licensed under a Creative Commons Attribution-ShareAlike 4.0 International License.

\section{PENDAHULUAN}

"Tenis meja merupakan salah satu cabang olahraga permainan yang mulai banyak diminati oleh masyarakat Indonesia, bahkan telah menjadi olahraga yang populer di dunia, hal ini disebabkan karena olahraga tenis meja tidak terlalu rumit untuk diikuti"(Asri 2017) "Permainan tenis meja memiliki beberapa teknik dasar, yaitu: 1) Servis yang terdiri dari servis forehand dan servis backhand, 2) Pukulan atau stroke dan 3) Block. Tiga teknik dasar tersebut, pukulan (stroke) merupakan salah satu teknik yang sangat penting dalam permainan tenis meja, karena pukulan juga ikut menentukan jalannya suatu permainan tenis meja" (Salim 2008)

"Teknik pukulan merupakan salah satu teknik dasar utama yang harus dikuasai dalam permainan tenis meja, tanpa mengesampingkan teknikteknik lainnya. Teknik dasar dalam permainan tenis meja yang sering dilakukan dan dikuasai adalah pukulan forehand" (Asri 2017). Pukulan forehand dianggap sebagai dasar pukulan karena pukulan ini mudah untuk dipelajari, "pukulan forehand biasanya merupakan pukulan yang paling kuat karena tubuh tidak menghalangi saat melakukan pukulan, tidak seperti backhand. Selain itu, otot yang digunakan biasanya lebih maksimal dari pada pukulan backhand" (Hodges 2007)

Berdasarkan hasil observasi di Sekolah Menengah Pertama Negeri 1 Tanjung Batu, kemampuan teknik dasar siswa masih terbilang rendah, hal ini bisa 
dilihat dari program latihan yang dilaksanakan selama ini belum tersusun dengan baik. Sehingga kemampuan siswa dalam melakukan teknik dasar berupa forehand drive masih tergolong rendah. Hal itu bisa dilihat ketika siswa melakukan pukulan forehand drive melalui media backboard dengan waktu 30 detik dan tiga kali kesempatan diperoleh nilai terbesar 16 pukulan yang dilakukan oleh 10 siswa, nilai terendah 5 pukulan yang dilakukan oleh 35 siswa dan 5- 11 pukulan dilakukan oleh 10 siswa.

(Sukadiyanto 2002) "mengungkapkan bahwa ada beberapa pengertian latihan dalam bentuk bahasa yaitu: Latihan yang berasal dari kata practice adalah aktivitas untuk meningkatkan keterampilan (kemahiran) berolahraga dengan menggunakan berbagai peralatan sesuai dengan tujuan dan kebutuhan cabang olahraganya. Latihan yang berasal dari kata exercise adalah perangkat utama dalam proses latihan harian untuk meningkatkan kualitas fungsi sistem organ tubuh manusia, sehingga mempermudah olahragawan dalam menyempurnakan geraknya. Latihan yang berasal dari kata training adalah penerapan dari suatu perencanaan untuk meningkatkan kemampuan berolahraga yang berisikan materi teori dan praktek, metode, dan aturan pelaksanaan sesuai dengan tujuan dan sasaran yang akan dicapai”.

Latihan yang maksimal sangat diperlukan untuk meningkatkan teknik pukulan dalam bermain tenis meja. Selain itu, yang terpenting adalah pemahaman teknik dasar yang ada dalam permainan tenis meja, yang bisa kita pelajari di sekolah, klub atau bisa kita dapatkan dari sumber-sumber terpercaya, baik sumber tertulis atau sumber internet.

"Secara khusus pentingnya pembinaan olahraga disekolah karena kegiatan olahraga dapat mengembangkan dan membangun kepribadian, watak, budi perkerti luhur dan moral tinggi serta inisiatif. Karena pnyelenggaraan pembinaan olahraga bagi individu dan masyarakat ini mengandung pendidikan yang positif, selain itu olahraga dapat menghilangkan rasa kedaerahan dan kesukuan serta mempertebal rasa persatuan dan kesatuan Nasional”(Riyoko 2019)

"Kualitas latihan merupakan suatu hal yang penting dalam usaha meningkatkan mutu dan prestasi seorang atlet. Latihan-latihan yang 
bermanfaat serta mempunyai arah dan tujuan yang jelas. Suatu latihan yang intensif belum dapat dikatakan sudah cukup bilamana latihan tersebut tidak disertai bobot, mutu, dan kualitas dari latihan itu sendiri. Dalam latihan juga perlu diperhatikan variasi latihan karena dengan adanya variasi-variasi dalam menghindarkan dari rasa bosan dan jenuh. Dalam latihan juga perlu diperhatikan variasi latihan karena dengan adanya variasi-variasi dalam menghindarkan dari rasa bosan dan jenuh" (Riyoko Endie, 2019).

"Keterampilan forehand drive dalam bermain tenis meja bisa ditingkatkan dengan menggunakan sebuah metode latihan yang efektif dan efisien serta dilaksanakan secara berulang-ulang dalam waktu yang cukup lama" (Asri 2017) Cabang olahraga tenis meja mempunyai banyak variasi latihan, salah satunya adalah latihan forehand ke dinding. (Hodges 2007) mengatakan bahwa "latihan forehand ke dinding ini dilakukan dengan memantulkan bola sebanyak mungkin secara berurutan dengan menggunakan sisi forehand bat". Bentuk latihan ini sangat tepat diberikan kepada atlet-atlet pemula agar kemampuan relinya meningkat dan konsistensi pukulan terjaga dengan memberikan sasaran ke dinding, sehingga dapat melakukan pukulan yang sama berkali-kali dan jatuh pada tempat yang sama.

"Pengenalan cara memukul bola tidak langsung dilakukan di atas meja, namun dapat dilakukan dengan latihan memukul bola" (Sunarsih 2009). Sarana dan prasarana yang dibutuhkan dalam melakukan latihan forehand ke dinding adalah sebagai berikut: 1) Bola, 2) Bola, 3) Dinding yang rata, 4) pluit. "Adapun cara latihannya adalah sebagai berikut: 1) Sikap awal berdiri dengan posisi kaki agak dibuka dengan menggunakan pegangan shakehand grip dan kira-kira 2'24”5.60" dari dinding. 2) Pukul bola dengan pukulan forehand menghadap ke dinding, pukul bola langsung ke depan. 3) gerakan yaitu memukul bola dengan tempat yang sama setiap kalinya dan kira-kira setinggi pundak. Pantulan bola yang dilakukan tanpa jatuh dan juga memperhatikan sasaran pukulan yang dipasang di dinding" (Hodges 2007).

(Kertamanah 2003) mengatakan bahwa "drive adalah pukulan yang paling kecil tenaga gesekannya. Pukulan drive yang sering juga disebut lift, merupakan dasar 
dari berbagai jenis pukulan serangan. Oleh karena itu, pukulan drive disebut pula sebagai induk teknik dari pukulan serangan”.

Pukulan drive adalah salah satu pukulan yang mempunyai kelebihan tersendiri dalam bermain tenis meja, beberapa kelebihan tersebut antara lain: 1) Tinggi atau rendah terbang bola diatas ketinggian garis net mudah dikuasai, 2) Cepat maupun lambatnya laju bola tidak akan susah dikendalikan, 3) Bola drive tidak mengandung tenaga yang terlalu keras, 4) Bola bersifat membawa sedikit perputaran, 5) Dapat dilancarkan disetiap posisi titik bola diatas meja tanpa merasakan kesulitan terhadap bola-bola berat, ringan, cepat, lambat, tinggi maupun rendah, serta terhadap berbagai jenis putaran bola. Drive merupakan salah satu teknik pukulan yang penting untuk menghadapi permainan defensif (Kertamanah 2003)

Simpulannya adalah, forehand drive merupakan salah satu pukulan yang sangat penting dalam permainan tenis meja, karena forehand drive merupakan pukulan yang paling kuat dan tenaga gesek yang dikeluarkan juga sangat kecil. Selain itu forehand drive yang baik juga bisa menjadi salah satu pukulan yang mematikan bagi lawan bermain.

\section{METODE}

Penelitian ini merupakan metode eksperimen semu, dalam penelitian ini terdapat satu kelompok eksperimen yang sengaja diberi perlakuan. Rancangan penelitian ini adalah one group prestest-posttest design, yaitu satu kelompok yang diberikan perlakuan, tetapi sebelum perlakuan diberikan, terlebih dahulu dilakukan tes awal (pretest), kemudian diakhir perlakuan dilakukan tes akhir (posttest). 
"Populasi penelitian adalah keseluruhan subjek penelitian". Dalam penelitian ini populasi keseluruhan ada 40 siswa. Yaitu siswa putra kelas VIII Sekolah Menengah Pertama Negeri 1 Tanjung Batu. "Sampel penelitian adalah sebagian ataupun wakil populasi yang diteliti”. Kemudian (Arikunto 2002) juga mengatakan jika sampel kurang dari 100, lebih baik semua objek dijadikan sampel sehingga penelitiannya merupakan penelitian populasi. Selanjutnya jika jumlah subjeknya besar dapat diambil $10-15 \%$ ataupun $20-25 \%$ atau lebih, tergantung setidak-tidaknya dari:

1. Kemampuan peneliti dilihat dari waktu, tenaga dan dana.

2. Sempit luasnya wilayah pengamatan dari setiap subjek, karena hal itu menyangkut banyaknya sedikit data.

3. Besar kecilnya resiko yang ditanggung oleh peneliti.

Tabel 1. Jumlah keseluruhan siswa putra yang diteliti

\begin{tabular}{|c|c|c|}
\hline No & Kelas & Jumlah Siswa \\
\hline 1 & VIII 1 & 8 \\
\hline 2 & VIII 2 & 12 \\
\hline 3 & VIII 3 & 11 \\
\hline 4 & VIII 4 & 9 \\
\hline \multicolumn{2}{|c|}{ Jumlah } & 40 \\
\hline
\end{tabular}

Tabel 2. One group pretest and posttest design

\begin{tabular}{|c|c|c|}
\hline Pretest & Treatment & Posttest \\
\hline $\mathrm{O}_{1}$ & $\mathrm{X}$ & $\mathbf{O}_{2}$ \\
\hline
\end{tabular}

Keterangan:

$\mathrm{O}_{1} \quad$ : Tes awal (pretest) sebelum perlakuan diberikan

$\mathrm{X}$ : Perlakuan terhadap kelompok eksperimen yaitu dengan menerapkan latihan

forehand ke dinding

$\mathrm{O}_{2} \quad$ : Tes akhir (posttest) setelah perlakuan diberikan 


\section{HASIL DAN PEMBAHASAN}

Penelitian ini dilakukan pada tanggal 1 Nopember sampai dengan 14 Desember 2019 di Sekolah Menengah Pertama Negeri 1 Tanjung Batu. Subjek dalam penelitian ini adalah seluruh siswa putra kelas VIII Sekolah Menengah Pertama Negeri 1 Tanjung Batu. Sebelum diberikan perlakuan berupa latihan forehand ke dinding, terlebih dahulu siswa diberikan pretest dengan melakukan forehand drive menggunakan media backboard, tujuannya adalah untuk mencai reliabilitas, perangkingan, membagi subjek menjadi dua kelompok dan untuk membandingkan dengan hasil posttest. Hasil dari penelitian ini selanjutnya akan dideskripsikan sebagai berikut:

\section{Deskripsi Data Hasil Pretest Forehand Drive Siswa Putra Kelas VIII}

\section{SMP Negeri 1 Tanjung Batu Dengan Instrumen Tes Backboard}

Berdasarkan hasil pretest forehand drive menggunakan instrumen tes backboard yang dilakukan oleh 40 orang sampel dengan waktu 30 detik dan tiga kali kesempatan, diperoleh rata-rata (mean) adalah 9,45, Standar Deviasi adalah 2,70, skor tertinggi 16 dan skor terendah 5, rentangya adalah 11 .

Tabel 3. Distribusi Data Pretest Forehand Drive Menggunakan Media Backboard

\begin{tabular}{|c|c|c|c|c|c|c|}
\hline Variabel & N & $\begin{array}{c}\text { Skor } \\
\text { Tertinggi }\end{array}$ & $\begin{array}{c}\text { Skor } \\
\text { Terendah }\end{array}$ & Rentang & Mean & SD \\
\hline $\begin{array}{c}\text { Forehand } \\
\text { Drive }\end{array}$ & 40 & 16 & 5 & 11 & 9,45 & 2,70 \\
\hline
\end{tabular}

\section{Deskripsi Data Hasil Posttest Forehand Drive Siswa Putra Kelas VIII} SMP Negeri 1 Tanjung Batu Dengan Instrumen Tes Backboard

Berdasarkan hasil posttest forehand drive menggunakan instrumen tes backboard yang dilakukan oleh 40 orang sampel dengan waktu 30 detik dan tiga kali kesempatan, diperoleh rata-rata (mean) adalah 11,3, Standar Deviasi adalah 2,78, skor tertinggi 18 dan skor terendah 7, rentangya adalah 11 . 
Tabel 4. Distribusi Data Posttest Forehand Drive Menggunakan Media Backboard

\begin{tabular}{|c|c|c|c|c|c|c|}
\hline Variabel & N & $\begin{array}{c}\text { Skor } \\
\text { Tertinggi }\end{array}$ & $\begin{array}{c}\text { Skor } \\
\text { Terendah }\end{array}$ & Rentang & Mean & SD \\
\hline $\begin{array}{c}\text { Forehand } \\
\text { Drive }\end{array}$ & 40 & 18 & 7 & 11 & 11,3 & 2,78 \\
\hline
\end{tabular}

\section{Hasil (Deskripsi dan Analisis Data)}

\section{a. Uji Normalitas Data}

Uji normalitas data merupakan syarat yang harus dilakukan sebelum menganalisis data uji hipotesis, data yang diuji dari hasil pretest dan posttest dengan menggunakan rumus koefisien pearson $\mathrm{k}=\frac{\pi-\mathrm{m} 0}{\mathrm{~s}}$ (Sudjana, 2005:109) Keterangan:

$\mathrm{K}=$ Kemiringan

$\Pi \quad=$ Rata-rata

$\mathrm{m}_{0} \quad=$ Modus

$\mathrm{s} \quad=$ Simpangan

Data dikatakan normal jika nilai $\mathrm{K}$ terletak antara -1 sampai +1 ($1<\mathrm{K}<+1)$. Karena nilai KM sebesar 0,52 dan harga ini terletak antara (-1) dan $(+1)$ maka data tersebut berdistribusi normal.

\section{b. Uji Hipotesis}

Setelah data dinyatakan berdistribusi normal, maka selanjutnya dapat dilakukan pengujian hipotesis dengan rumus Uji t:

$$
\begin{aligned}
& t=\frac{M d}{\sqrt{\frac{\sum X^{2} d}{N(N-1)}}} \\
& M d=\frac{\sum d}{N} \\
& \sum X^{2} d=\Sigma d^{2}-\frac{(\Sigma d)^{2}}{N}
\end{aligned}
$$


keterangan:

t $\quad$ : nilai yang dihitung statistik

Md : Mean dari perbedaan pretest dengan posttest

$\sum x^{2} d \quad$ : Jumlah kuadrat deviasi

$\mathrm{N} \quad$ : Subjek pada sampel

Jika t hitung yang didapat adalah 18 sedangkan t tabel adalah 1,70 diperoleh dari tabel distribusi t dengan dk (40), maka 40-1=39 dan taraf kepercayaan 95\% $(\alpha=0,05)$. Kriteria pengujian hipotesisnya yaitu terima $\mathrm{H}_{0}$ jika $\mathrm{t}$ hitung $<\mathrm{t}$ tabel (1$\alpha$ ) dan tolak $\mathrm{H}_{0}$ jika $\mathrm{t}$ hitung $>\mathrm{t}$ tabel $(1-\alpha)$, t 1- $\alpha$ adalah $\mathrm{t}$ yang terdapat dalam tabel distribusi $\mathrm{t}$ dengan $\mathrm{dk}=\mathrm{n} 1+\mathrm{n} 2-1$ dan peluang (1- $\alpha)$. Jika $\mathrm{t}$ hitung yang diperoleh adalah 18 dengan $\mathrm{dk} 40-1=39$ dan taraf kepercayaan $0,95 \%(\alpha=0,05)$ maka dapat menghitung nilai $\mathrm{t}$ tabel karena $\mathrm{dk}=39$ yang terdapat pada tabel adalah 1,70. Karena $\mathrm{t}$ hitung $(11,3)>\mathrm{t}$ tabel $(1,70)$ maka terdapat perbedaan yang signifikan antara tes awal (pretest) dan tes akhir (Posttest). Dengan demikian maka hipotesis $\mathrm{H}_{0}$ ditolak dan hipotesis $\mathrm{H} 1$ diterima pernyataan $\mathrm{H} 1$ adalah "Ada Pengaruh Latihan Forehand ke Dinding Terhadap Hasil Forehand Drive Tenis Meja Pada Siswa Sekolah Menengah Pertama Negeri 1 Tanjung Batu”.

\section{KESIMPULAN}

Berdasarkan analisa data hasil penelitian dapat disimpulkan bahwa ada pengaruh latihan forehand ke dinding terhadap hasil forehand drive diterima kebenarannya. Hal ini diperkuat dari hasil pengujian hipotesis dimana thitung > ttabel atau 11,3 > 1,70. Besarnya peningkatan forehand drive setelah mengikuti latihan forehand ke dinding adalah 1,85. Dengan demikian, latihan forehand ke dinding dapat digunakan untuk meningkatkan forehand drive Tenis Meja. 


\section{DAFTAR PUSTAKA}

Arikunto. 2002. "Manajemen Penelitian."

Asri, Novri. 2017. "Pengaruh Metode Latihan Multiball Dan Koordinasi Mata Tangan Terhadap Peningkatan Keterampilan Forehand Drive Tenis Meja."JPES

UNNES

https://journal.unnes.ac.id/sju/index.php/jpes/article/view/17393.

Hodges, L. 2007. “Tenis Meja Tingkat Pemula. Jakarta."

Kertamanah, A. 2003. “Teknik \& Taktik Dasar Permainan Tenis Meja.”

Riyoko, Endie. 2019. "Riyoko, Endie. (2019). Pengaruh Permainan Sepakbola https://doi.org/10.33557/jurnalolympia.v1i1.294.

Salim, A. 2008. "Buku Pintar Tenis Meja. Bandung : Nuansa."

Sukadiyanto, Sukadiyanto. 2002. "Teori Dan Metodologi Melatih Fisik."

Sunarsih, Sri dkk. 2009. "Pendidikan Jasmani Olahraga Dan Kesehatan." Erlangga. 